\title{
Long-term projections of the hourly electricity consumption in Danish municipalities
}

M. Andersen, F.; Henningsen, Geraldine; Møller, Niels Framroze; Larsen, Helge V.

Published in:

Energy

Link to article, DOI:

10.1016/j.energy.2019.115890

Publication date:

2019

Document Version

Publisher's PDF, also known as Version of record

Link back to DTU Orbit

Citation (APA):

M. Andersen, F., Henningsen, G., Møller, N. F., \& Larsen, H. V. (2019). Long-term projections of the hourly electricity consumption in Danish municipalities. Energy, 186, [115890].

https://doi.org/10.1016/j.energy.2019.115890

\section{General rights}

Copyright and moral rights for the publications made accessible in the public portal are retained by the authors and/or other copyright owners and it is a condition of accessing publications that users recognise and abide by the legal requirements associated with these rights.

- Users may download and print one copy of any publication from the public portal for the purpose of private study or research.

- You may not further distribute the material or use it for any profit-making activity or commercial gain

- You may freely distribute the URL identifying the publication in the public portal

If you believe that this document breaches copyright please contact us providing details, and we will remove access to the work immediately and investigate your claim 
Data file for "Long-term projections of the hourly electricity consumption in Danish municipalities".

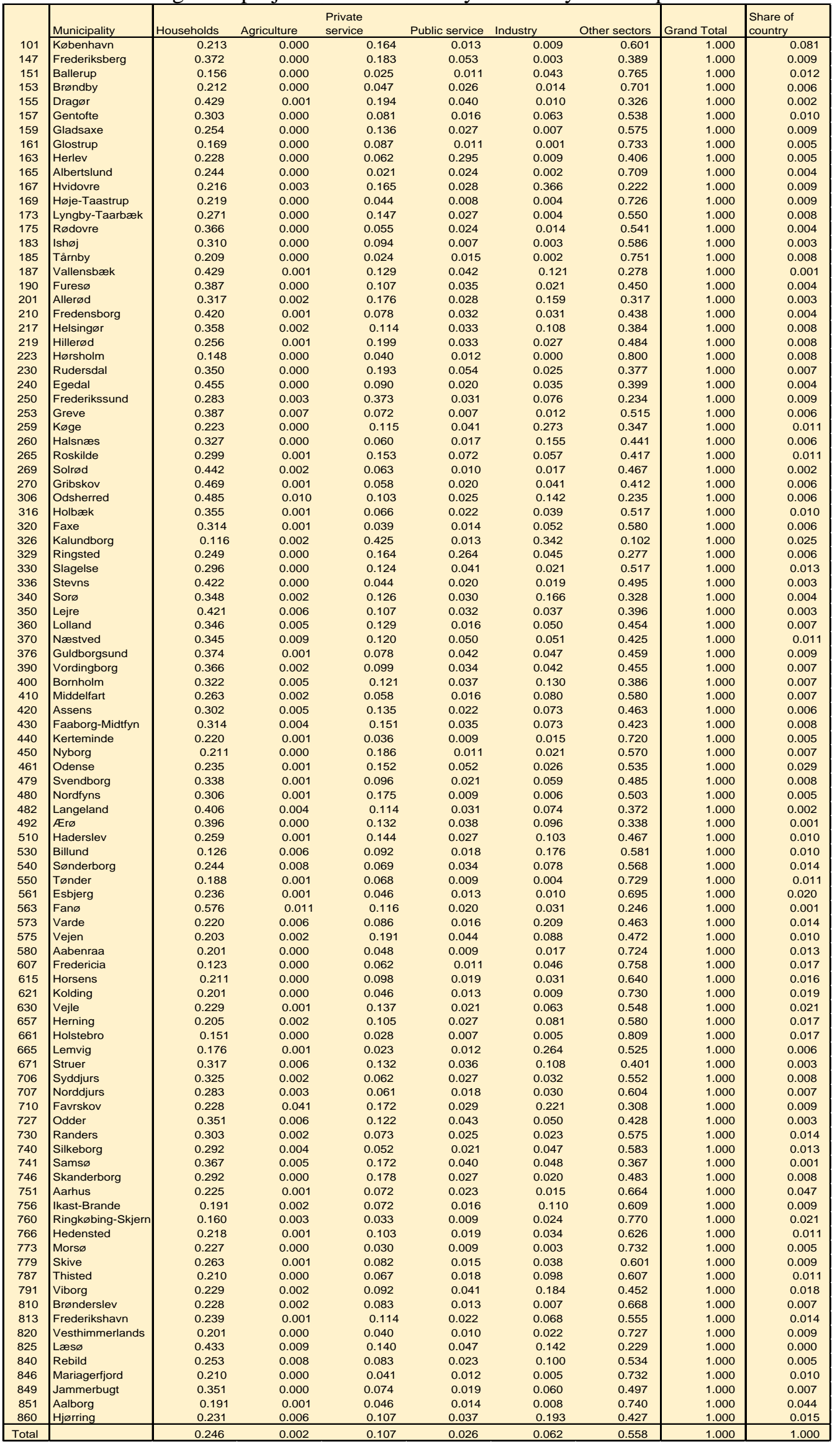

Table A1. The share of consumption by categories in municipalities in Denmark. 


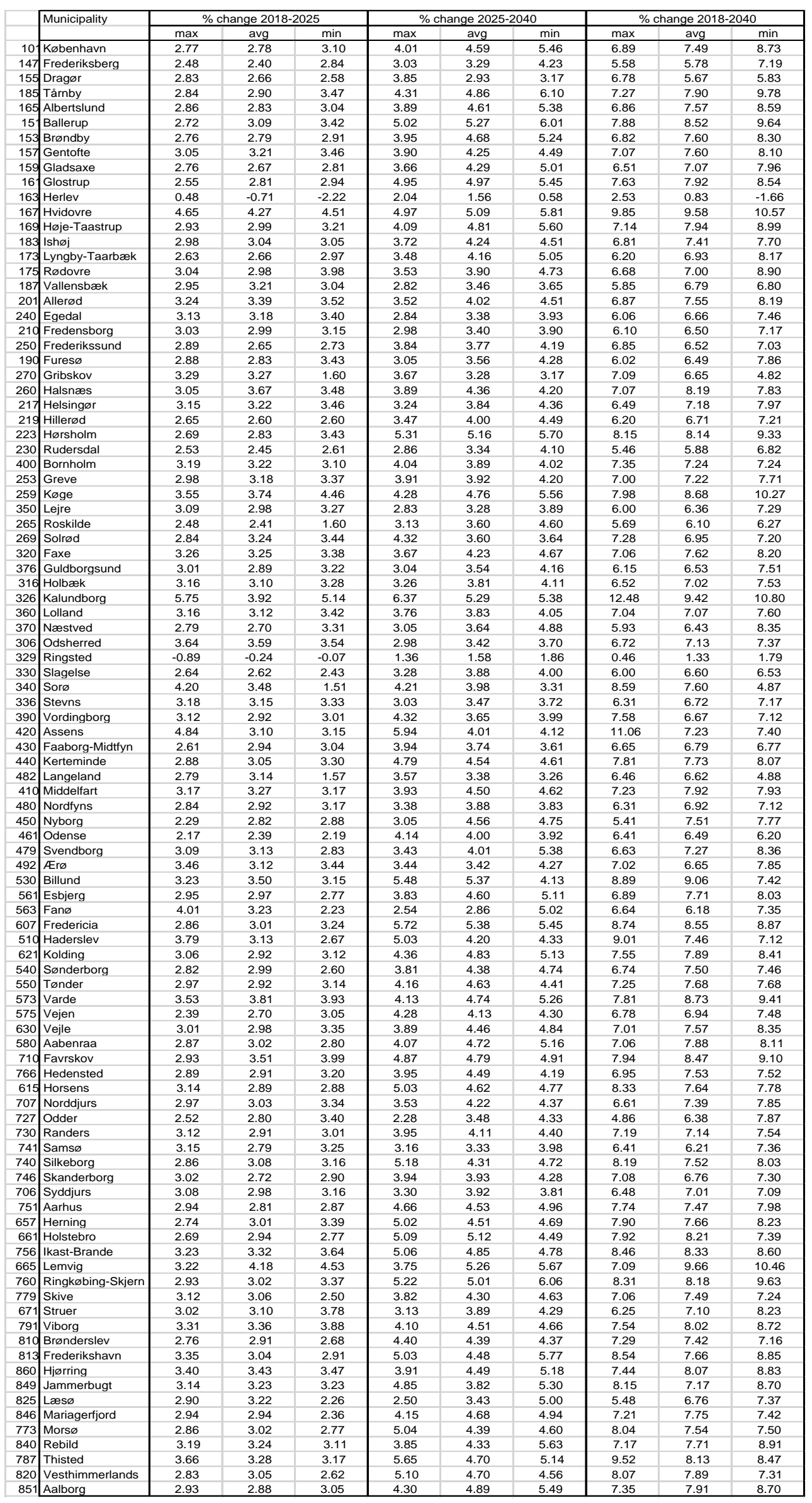

Table A2. Change in the classic consumption in municipalities. 


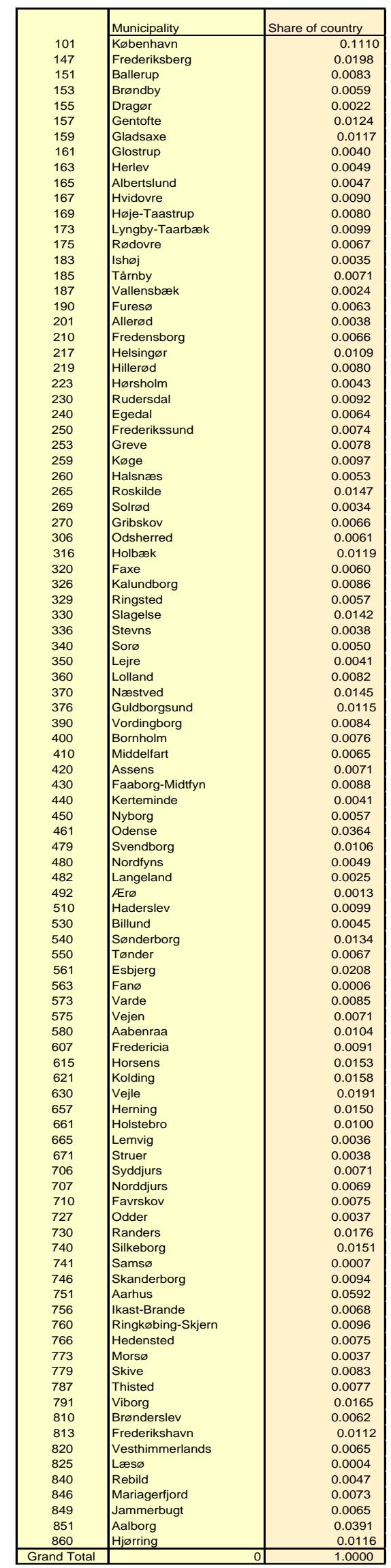

Table A3. Share of households in municipalities.

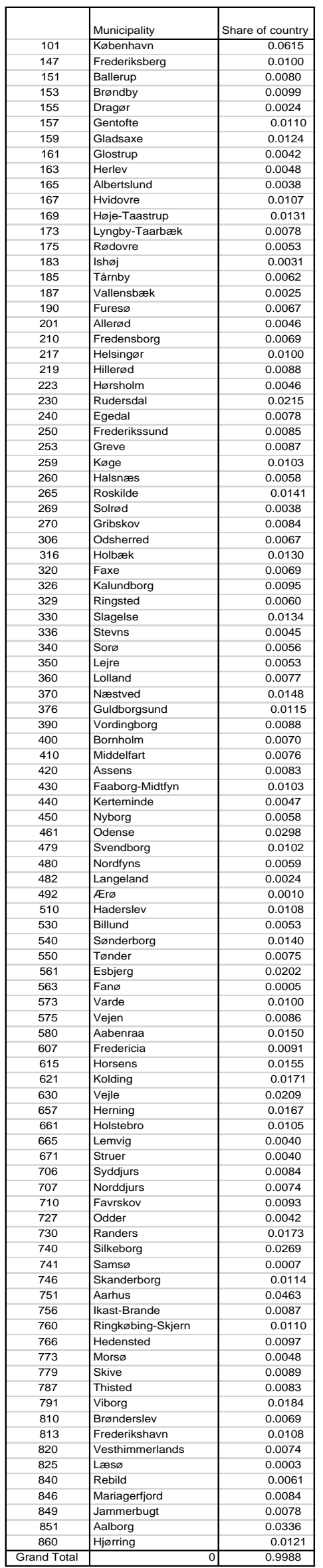

Table A5. Share of cars in municipalities 


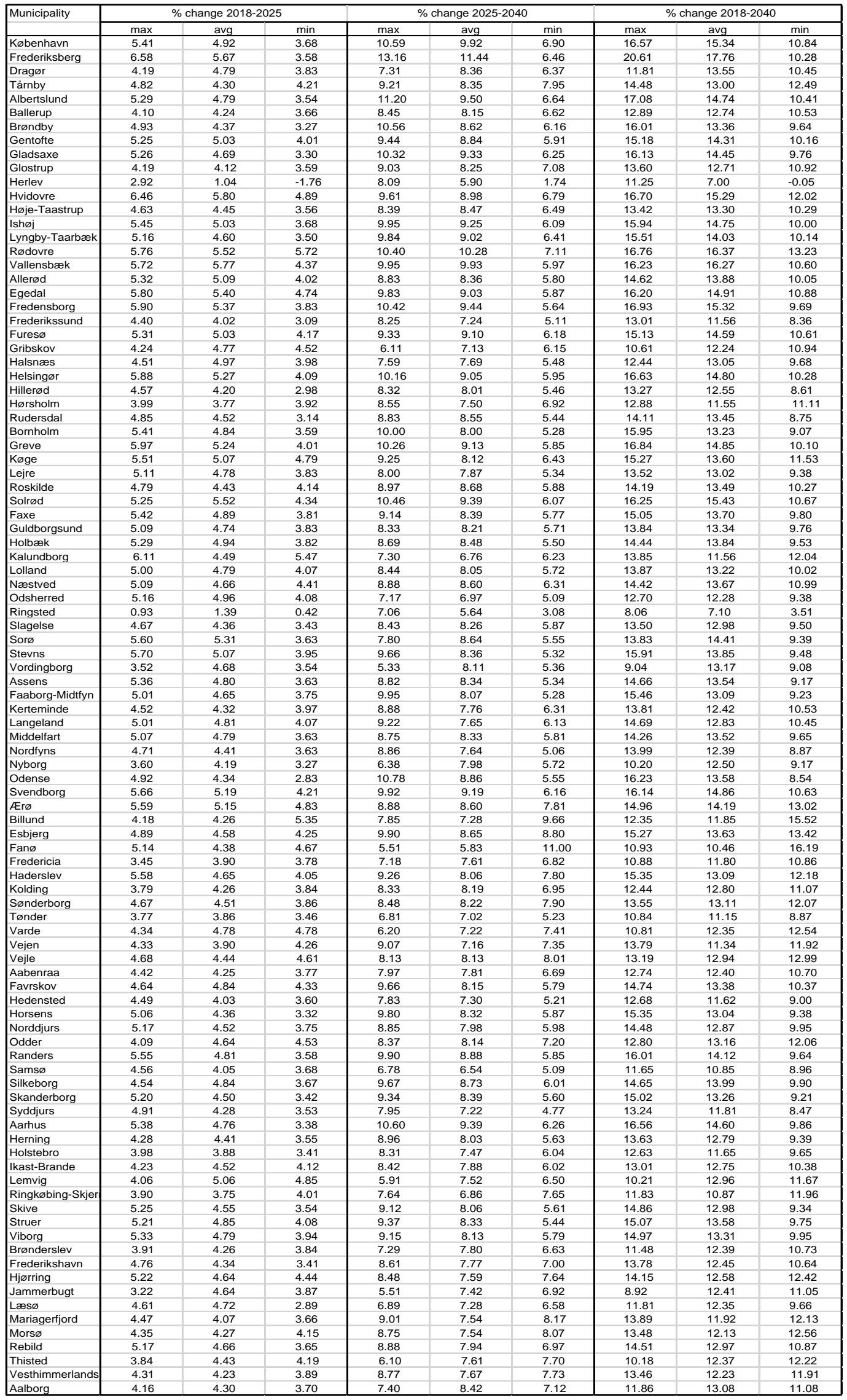

Table A4. Change in consumption incl. individual heat pumps in municipalities. 


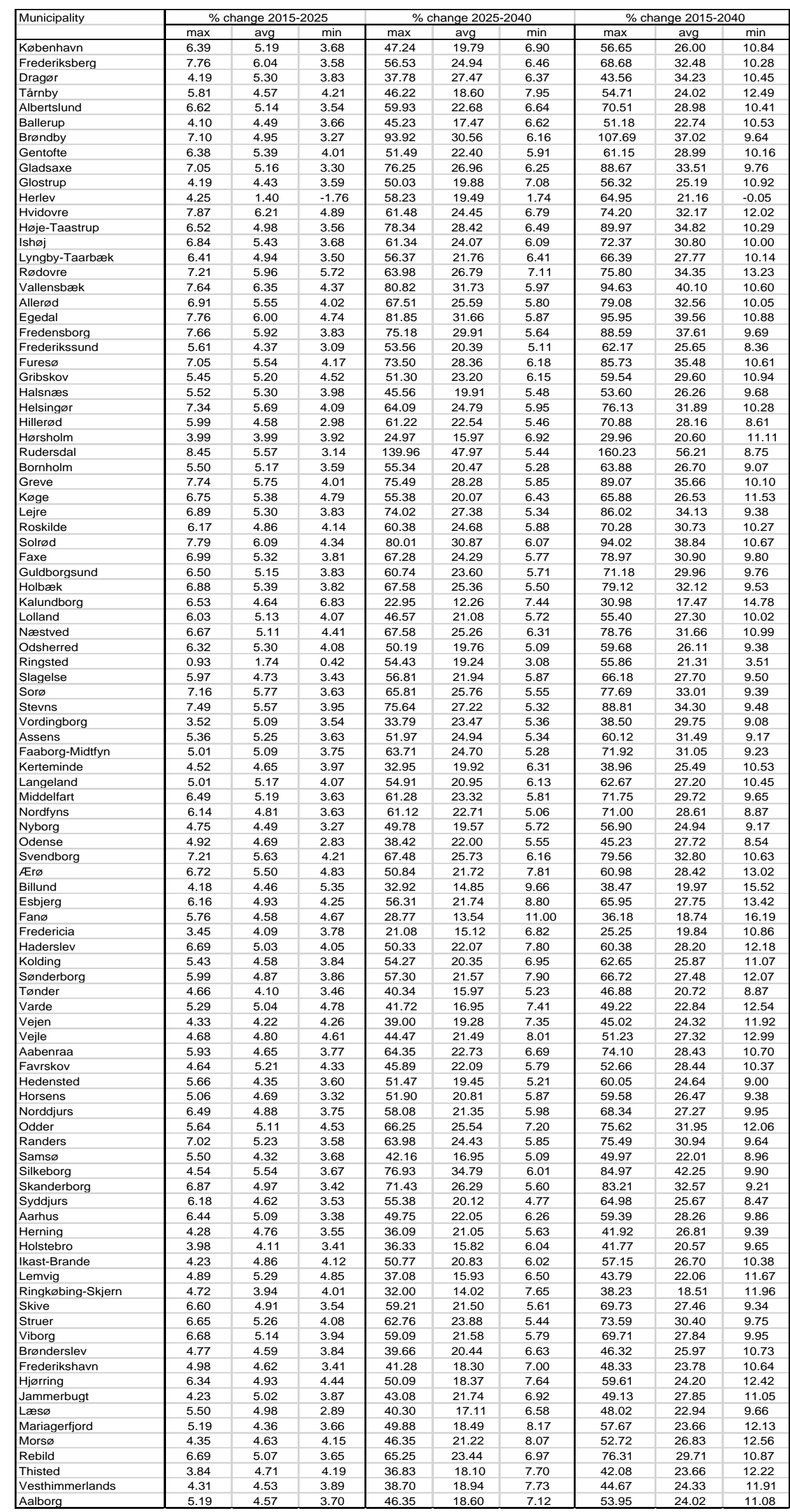

Table A6. Changes in consumption incl. electric vehicles. (Profile: worst case charging) 


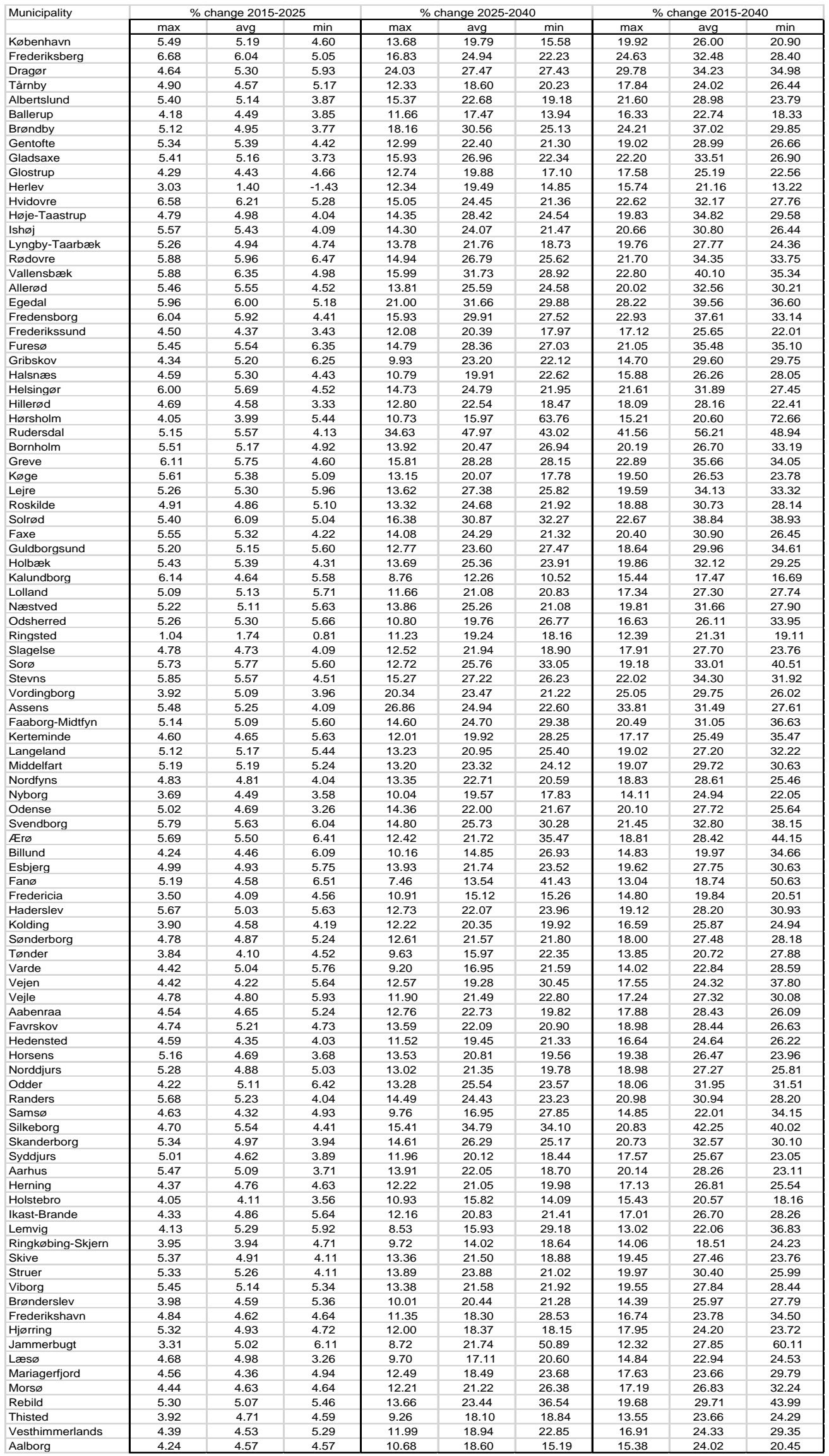

Tabel A7. Changes in consumption incl. electric vehicles (Profile: Charging mainly during the night) 